\author{
JACEK SIERADZAN \\ Uniwersytet w Białymstoku \\ Instytut Filozofii \\ e-mail: j.sieradzan@uwb.edu.pl \\ ORCID: 0000-0002-3941-357X
}

\title{
Szaleństwo jako norma. Antynomizm w działaniu żołnierzy, mafii, państw i korporacji
}

\begin{abstract}
The article is illustration of Victora Turner's approach concerning liminality of phenomena both in social and ethical dimension. It shows liquid borders between state and self-defence social movements which from informal communitas transform into criminal organizations, and in time became states in state. The border between state and criminal organization can become liminal. Liminality of border between good and bad means not only that the same persons who in time of peace condem evil, during war glorify killing. It means also changing hierarchy of values in time of peace. As profitable and also good is regarded what serves smaller social group existing within the confines of bigger groups, for example criminal organization in a state, one state in the confines of community of states, or transnational corporation in world. In a country dominated by criminal organizations, crime is regarded as normalcy, and normalcy is treated as something curious and incomprehesible. Desire to improvement one's social status at all costs is leading to criminalization of life and to living in permanent fear.
\end{abstract}

Keywords: liminality, crime, war, mafia, ethics 
„Ducha mafii zrodziło poczucie sprawiedliwości społecznej”1.

Maria-Anne Matard-Bonucci

V ictor Turner pisał o liminalności zjawisk zarówno w wymiarze społecznym, jak i etycznym. Odwołując się do jego podejścia, można pokazać płynność granic między państwem a ruchami samoobrony społecznej, które z nieformalnych antystruktur (nazywanych przez Turnera communitas) przekształcają się w organizacje przestępcze i stają państwami w państwie. Turner zauważył, że owe marginalne, usytuowane na obrzeżach społeczeństwa communitas, z czasem stają się organizacjami głównego nurtu i zaczynają wywierać dominujący wpływ na życie społeczne ${ }^{2}$. Tak było z religiami uniwersalistycznymi, które zaczynały jako kilkuosobowe sekty, tak było z raczkującym w feudalizmie kapitalizmem, tak też stało się z organizacjami przestępczymi (notabene, zarówno kapitalizm, jak i mafia to włoskie wynalazki).

Przenikanie się interesów władzy feudalnej i przestępczości zauważył już w 1770 r. Patrick Brydone: „Najzuchwalsi i najbardziej zatwardziali bandyci tych okolic, którzy w każdym innym kraju byliby już łamani kołem lub zakuci w łańcuchy, tu przeciwnie, są jawnie chronieni, wszyscy boją się ich i poważają”3 . Co najmniej od XVI wieku feudałowie wynajmowali jednych bandytów do obrony przed innymi bandytami ${ }^{4}$. Mafia sycylijska powstała dla obrony interesów tubylców przed obcymi, a stała się państwem w państwie, ponadnarodową korporacją obracającą dziesiątkami miliardów dolarów rocznie i dającą zatrudnienie ponad 1,7 mln ludzi w samych tylko Włoszech (choć w tym kraju członków różnych zorganizowanych grup przestępczych jest znacznie mniej) ${ }^{5}$.

\footnotetext{
${ }^{1}$ M.-A. Matard-Bonucci, Historia mafii, Grupa Wydawnicza Bertelsmann, Warszawa 2001, s. 22.

${ }^{2}$ V. Turner, Proces rytualny. Struktura i antystruktura, PIW, Warszawa 2010, ss. 140-141.

${ }^{3}$ P. Brydone, A Tour Through Sicily and Malta, vol. 1, W. Strahan and T. Cadell, London 1773, s. 68.

${ }^{4}$ M.-A. Matard-Bonucci, Historia mafii, s. 42.

${ }^{5}$ Szacunkowo, w Kalabrii 25\% ludności (czyli 500000 osób) należy do Ndranghety, w Kampanii 12\% (czyli 680 000) należy do kamorry, na Sycylii 10\% (czyli 500000 osób) należy do mafii, a w Apulii 2\% (czyli 80000 osób) należy do Zjednoczonej Świętej Korony. Zob. P. Reski, Mafia, Bellona, Warszawa 2017, s. 131. Inna autorka szacowała, że do trzech pierwszych organizacji w 1990 r. należało łącznie 18200 osób. Zob. M.-A. Matard-Bonucci, Historia mafii, s. 6.
} 


\title{
1. Płynność granicy między państwem a organizacją przestępczą
}

\author{
„Teraz państwo to ja. I mnie należą się podatki”6.
}

Toto Riina, były boss Cosa Nostry

Inną rzeczą, na którą zwrócił uwagę Turner, jest płynność granic między zjawiskami; nazwał ją liminalnością. Granice między prawem a bezprawiem, wojną a pokojem, normalnością a szaleństwem, realnością a fikcją, prawdą a fałszem są rozmyte. Kapitalizm ujawnił płynność granic między człowiekiem bezrobotnym, umierającym z głodu i kryminalistą. Bezrobotni to łatwy łup dla organizacji przestępczych, w ich ramach stają się oni kryminalistami ${ }^{7}$. Partie, które wygrały demokratyczne wybory (jak NSDAP w Niemczech), stają się organizacjami przestępczymi, a organizacje przestępcze legitymizują swoje działanie (co stało się z mafią w USA czy mafią i kamorrą we Włoszech i Szkocji) ${ }^{8}$. Państwa współpracują z producentami narkotyków (jak Nikaragua sandinistów z Kolumbijczykami) albo same produkują narkotyki (jak Korea Północna). Tę płynność wykorzystują organizacje przestępcze (jak kamorra), mamiące młodych ludzi szybką ścieżką kariery. To samo czynią też partie populistyczne, szermujące nadzieją na szybką zmianę sytuacji i poprawę sytuacji życiowej wszystkich bez wyjątku. Analitycy wskazują też na podobieństwo wielkich instytucji finansowych (takich jak bank J.P. Morgan) do kasyn, a ich obietnice łatwego i szybkiego wzbogacenia się do pustych obietnic populistycznych polityków ${ }^{9}$.

Roberto Saviano pokazał, w jaki sposób państwo włoskie przyczyniło się do rozbudowy potęgi kamorry. Jej członkowie nie musieli zastraszać polityków, bo ci sami dawali kontrakty i licencje ludziom związanym z kamorrą, a ta zgodnie ze swoimi zasadami raz zdobytych terytoriów nie oddaje. W analogiczny sposób w latach 40. XX wieku mówił Władysław Gomułka, lider polskich komunistów: „Władzy, raz zdobytej, nie oddamy nigdy”10. Politycy, którzy ulegli kamorze, należeli do różnych partii - od skompromitowanej wcześniej współpracą z mafią sycylijską chadecji po partię komunistyczną ${ }^{11}$.

${ }^{6}$ Cyt. za: J. de Saint Victor, Niewidoczna siła. Mafia w społeczeństwach demokratycznych, Czarne, Wołowiec 2015, s. 231.

${ }^{7}$ K. Marks, Rękopisy ekonomiczno-filozoficzne z 1844 r. (Fragmenty), w: idem, Pisma wybrane. Człowiek i socjalizm, PWN, Warszawa 1979, s. 113.

${ }^{8}$ Przykładowo, Szkocja odmówiła wydania Włochom Antonia La Torre, jednego z bossów kamorry, który w Szkocji był ceniony jako znakomity przedsiębiorca. Zob. R. Saviano, Gomorra. Podróż po imperium kamorry, Czytelnik, Warszawa 2008, s. 294.

${ }^{9}$ Ł. Wójcik, Bank populizmu, „Polityka” 38/2017, s. 36.

${ }^{10}$ Cyt. za: M. Mirowski, Wiesław nieoczywisty, „Polityka” 36/2017, s. 62.

${ }^{11}$ Sycylijski oddział chadecji mieścił się w Corleone, jednym z siedlisk mafii. Zob. M.-A. Matard-Bonucci, Historia mafii, s. 179. 
Organizacje przestępcze tak bardzo przeniknęły struktury państwa, że granica między nimi a państwem stała się liminalna. Z jednej strony mafiosi mordowali nieskorumpowanych polityków i sędziów, a z drugiej strony kandydaci w wyborach szantażowali mafiosów, że jeśli ci nie poprą ich w wyborach, to potem rozprawią się z nimi ${ }^{12}$. Siła mafii bierze się stąd, że ludzie obawiają się jej bardziej niż państwa ${ }^{13}$. Interesy urzędników państwowych i członków organizacji przestępczych wzajemnie się przenikają ${ }^{14}$. Celnie wyraził to Guy Debord, cytując maksymę sycylijskiej mafii: „kto ma pieniądze i przyjaciół, może drwić z prawa”15.

\section{Stefan Dąmbski, zabójca z Armii Krajowej}

W 2010 r. Ośrodek KARTA opublikował książkę Stefana Dąmbskiego Egzekutor. Jej autor pisze, że podczas II wojny światowej na zlecenie Armii Krajowej (AK) wykonał dziesiątki wyroków śmierci. Praca ta wzbudziła kontrowersje nie tylko dlatego, że Dąmbski bez żadnych zahamowań opisuje zabijanie ludzi, głównie Polaków, ale także z tego powodu, że choć książkę opublikowano w serii literatury faktu, nie ma pewności, że mamy do czynienia ze wspomnieniami ${ }^{16}$. Wydaje się raczej, że jest to fikcja literacka przemieszana z faktami, co nazywa się dokufikcją lub niefikcyjną powieścią, czyli gatunkiem łączącym fikcję z niefikcją ${ }^{17}$. Czytając jego książkę, można odnieść wrażenie, że jej autor przypisał sobie zabójstwa, które dokonali inni członkowie grup likwidacyjnych. Stworzył legendę siebie jako nieustraszonego kilera wykonującego wprawdzie zlecenia AK, ale działającego w dużej mierze samodzielnie. W podobny sposób działają kamoryści wykonujący

12 J. de Saint Victor, Niewidoczna siła..., s. 147.

${ }^{13}$ Z dwojga rzeczy „prawa i mafii, to pierwsze jest mniej groźne”. G. Alongi, cyt. za: M.-A. Matard-Bonucci, Historia mafii, s. 122.

${ }^{14}$ Por. np. R. Saviano, Gomorra..., ss. 54-58.

15 G. Debord, Rozważania o społeczeństwie spektaklu, w: idem, Społeczeństwo spektaklu. Rozważania o społeczeństwie spektaklu, PIW, Warszawa 2006, ss. 198-199.

${ }^{16}$ Wydawca, Zbigniew Gluza, uważa ją za „prawdziwą”. Zob. Z. Gluza, Od KARTY, w: S. Dąmbski, Egzekutor, Wydawnictwo Naukowe PWN, Warszawa 2013, s. 7. Mieczysław Skotnicki, były żołnierz AK, zarzucił Dąmbskiemu mijanie się z prawdą historyczną i sadyzm. Kłamstwo i sadyzm zarzuciła mu także Irena Filipowicz, córka żołnierzy AK, działająca w konspiracji w rejonie opisanym przez Dąmbskiego (Wokół Egzekutora, S. Dąmbski, Egzekutor, ss. 120-128). Historyk Dariusz Stola nigdzie nie mówi, że opowieść Dąmbskiego to fikcja; raz nazywa ją wspomnieniami, raz pamiętnikiem. Zob. Przemoc chwalebna: Z prof. Dariuszem Stolq o ksiq̨żce Stefana Dąmbskiego „Egzekutor” rozmawia Piotr Lipiński, „Duży Format”, dodatek do „Gazety Wyborczej” nr 42 z 2010 r., s. 14. Inny historyk Grzegorz Ostasz wyraził opinię, „że narrator dał się ponieść fantazji”. Zob. Wokół Egzekutora, s. 130. Jego zmyślanie tłumaczy nieświadomością i niesprawną pamięcią. Zob. ibidem, s. 133.

17 Tak określono też książkę R. Saviano Gomorra. Saviano nie podał ani jednego źródła swoich informacji, nie uważa się też za dziennikarza. Zob. Roberto Saviano: męczennik za prawdę czy zwykły oszust?, Onet, 5.11.2015, http://ksiazki.onet.pl/roberto-saviano-meczennikza-prawde-czy-zwykly-oszust/w8npq6 [17.08.2017]. 
wyroki śmierci na zlecenie swoich szefów, ale sami decydujący o wyborze metod egzekucji.

\section{Inicjacja - wstąpienie do organizacji}

Dąmbski wstąpił do AK w 1942 r., gdy miał 16 lat. Wkupił się do dywersji AK propozycją wykonania wyroku na współpracowniku gestapo, który był jego kolegą. Do wykonania wyroku zgłosił się na ochotnika, licząc na spektakularną karierę w dywersji ${ }^{18}$.

Kamorra rekrutuje chłopców w wieku od 12 do 17 lat, kiedy łatwo ich ukształtować. Wywodzą się z rodzin należących do kamorry lub bezrobotnych. (Najczęściej nadal chodzą do szkoły, aby nie wzbudzać podejrzeń policji ${ }^{19}$. Piętnastolatek zarabiający w jeden dzień około tysiąca euro nie należy do rzadkości ${ }^{20}$. Młodociany kamorysta wkupuje się do organizacji, oddając przestępcom znalezioną broń i narkotyki.

\section{Szacunek dla morderców}

„Sam uważam się za mafiosa, ponieważ mafia w dawnym sensie słowa oznacza odwagę, lojalność, honor i sprawiedliwość”21.

Vittorio Emanuele Orlando, profesor prawa i premier Włoch (1921)

Świeżo zwerbowani do kamory chłopcy obnoszą się z bronią po mieście. Fakt, że wzbudzają u innych strach, imponuje im i podnosi ich wartość w oczach innych ${ }^{22}$. W filmie „Akcja pod Arsenałem” (1978) młody polski konspirator czasów wojny wchodzi do tramwaju z widoczną bronią. Na jego widok konduktor mówi z szacunkiem: „wojskowi nie płacą”.

Sposobem na zyskanie uwagi i szacunku innych jest władza nad życiem i śmiercią. Saviano opisuje ją słowami: Mieć tę władzę [nad innymi - J.S.] przez dziesięć lat, przez rok, przez godzinę. To nie najważniejsze; ważne, żeby żyć naprawdę,

18 S. Dąmbski, Egzekutor, s. 15.

19 R. Saviano, Gomorra..., ss. 122-123. Także japońska Yakuza rekrutuje młodzież, 13-, 14-letnich chłopców. Zob. R. Tomański, Tatami kontra krzesła. O Japończykach i Japonii, Warszawskie Wydawnictwo Literackie Muza, Warszawa 2011, s. 47.

20 R. Saviano, Gomorra..., s. 124.

${ }^{21}$ Cyt. w: J. Bouček, Ośmiornica. Historia sycylijskiej mafii, Marpress, Gdańsk 1992, s. 38. Orlando był premierem rządu włoskiego podczas I wojny światowej, a następnie przedstawicielem Włoch na konferencji pokojowej w Wersalu.

22 R. Saviano, Gomorra..., s. 123. 
żeby naprawdę rządzić - tylko to się liczy”23. Jeden z młodocianych kamorystów pisał: „chcę, żeby wszyscy czuli respekt [...] chcę umrzeć [...] jak prawdziwy mężczyzna, taki, który naprawdę rządzi”24.

Zyskanie szacunku innych to także marzenie każdego sycylijskiego gangstera. Jeden ze skruszonych mafiosów, Marcello Fava, wspomina:

To była dla mnie coś cudownego. Każdy marzył, aby go przyjęli do cosa nostry. Żeby być blisko tych osób, żeby być przez wszystkich poważanym. Obojętnie dokąd idziesz, nikt nie waży się ciebie zaczepiać. Należy ci się szacunek. Chociaż inni nie mogli nic wiedzieć, wyczuwali, że jesteś człowiekiem honoru. Że masz prawo do wszystkiego. Oni tacy są, mafiosi z Palermo. I tylko tam ${ }^{25}$.

W kwestii szacunku wzbudzanego bronią identyczny pogląd ma także William Powell, autor podręcznika dla anarchistów napisanego na podstawie odtajnionych materiałów armii amerykańskiej. W swojej Anarchistycznej ksiq̨żce kucharskiej pisał: „Wolność bazuje na szacunku, a szacunek trzeba sobie wywalczyć, przelewając krew"26.

\section{Rozkosz zabijania, przemoc seksualna a powstanie ludzkości i religii}

Dąmbski przyznawał: „Strzelałem do ludzi jak do tarczy na ćwiczeniach, bez żadnych emocji. Lubiłem patrzeć na przerażone twarze przed likwidacją, lubiłem patrzeć ma krew tryskającą z rozwalonej głowy”27.

To, co jeden z AK-owskich komentatorów książki Dąmbskiego nazwał sadyzmem $^{28}$, niektórzy filozofowie i historycy wiążą z seksualnym przeżyciem rozkoszy. Hannah Arendt pisała, że „głównym czynnikiem ludzkim w Auschwitz był sadyzm, a sadyzm ma naturę seksualną. [...] wyjątkowo dobre samopoczucie [oskarżonych] podczas całego procesu [...] jest jakby słodkim wspomnieniem wielkiej rozkoszy seksualnej”29. Daniel Goldhagen zauważył, że esesmani czerpali seksualną rozkosz z bicia więźniarek pejczem, które zwykle kończyło się śmiercią, i że miało to podtekst sadystyczno-masochistyczny ${ }^{30}$. Również Slavoj Žižek uważa,

23 Ibidem, s. 131.

24 Ibidem, s. 132.

25 P. Reski, Mafia, s. 13.

${ }^{26}$ Cyt. za: U. Jabłońska, Ksiq̨żka śmierci, „Duży Format”, dodatek do „Gazety Wyborczej” nr 29 z 2017 r., s. 18.

27 S. Dąmbski, Egzekutor, s. 28.

${ }^{28}$ Mieczysław Skotnicki, cyt. za: W. Kowalski, Egzekutor, https://dzieje.pl/ksiazka/egzekutor [26.10.2019].

29 H. Arendt, Odpowiedzialność i władza sq̨dzenia, Prószyński i S-ka, Warszawa 2006, s. 282.

30 D.J. Goldhagen, Gorliwi kaci Hitlera: Zwyczajni Niemcy i faszyzm, Prószyński i S-ka, Warszawa 1999, ss. 283-284. 
że podczas wojny Niemcy zabijali innych nie tylko z poczucia obowiązku czy na rozkaz, ale także dlatego, że zabijanie sprawiało im rozkosz ${ }^{31}$. Cechy sadyzmu nosi też potraktowanie niektórych ofiar kamorry, torturowanych przed śmiercią przez wiele godzin ${ }^{32}$.

Ale zabijanie daje nie tylko rozkosz, ale jest też doświadczeniem sacrofanum, życia w świętej przestrzeni, kontaktu z bóstwem itp. Antropolog religii Walter Burkert wskazał na ścisłe związki łączące zrytualizowaną przemoc z seksualnością33 oraz zabijaniem: „Człowiek staje się człowiekiem poprzez polowanie, wskutek aktu zabijania”34. „Składanie krwawych ofiar jest podstawowym doświadczeniem »świętości«. Homo religiosus postępuje i osiąga samoświadomość jako Homo necans”35, czyli Człowiek Zabijający. O ścisłym związku zabijania, powstania ludzkości i religii pisali też Zygmunt Freud i René Girard ${ }^{36}$.

\section{Nekromania, sadyzm a kult przeszłości}

Spośród 14 cech osobowości nekromańskiej wymienionych przez Ericha Fromma, najważniejsze w omawianym tu kontekście są: gorliwe przestrzeganie prawa i porządku, zabijanie w imię idei, fascynacja siłą i przemocą, traktowanie ludzi jak przedmiotów oraz zabijanie życia poprzez obsesyjną chęć jego kontrolowania ${ }^{37}$.

Z fascynacją przemocą wiąże się nekrofilia. Zdaniem Fromma nekrofilia i sadyzm są dwoma aspektami człowieka, który przedłożył posiadanie nad bycie, a pamięć nad doświadczenie teraźniejszości ${ }^{38}$. Tak o tym pisze:

Nekrofile lubują się w przeszłości. Ich uczucia są w podstawowej mierze sentymentalne, pielęgnują oni w pamięci uczucia, które przeżywali wczoraj, lub te, co do których wierzą, że przeżywali. Są zimni, oddani sprawie „Prawa i porządku”. Wartości, które uznają, są dokładnie odwrotnością tych, które zwykle wiążemy z normalnym życiem. Nie życie lecz śmierć ekscytuje i zaspokaja ich ${ }^{39}$.

${ }^{31}$ S. Žižek, Przekleństwo fantazji, Wydawnictwo Uniwersytetu Wrocławskiego, Wrocław 2001, ss. 119-120. Por. A. Leder, Prześniona rewolucja. Ćwiczenie z logiki historycznej, Wydawnictwo Krytyki Politycznej, Warszawa 2014, ss. 21-22.

32 Por. np. R. Saviano, Gomorra..., ss. 149-151.

${ }^{33}$ W. Burkert, Home Necans: The Anthropology of Ancient Greek Sacrificial Ritual and Myth, University of California Press, Berkeley 1983, s. 33.

${ }^{34}$ Ibidem, s. 22.

35 Ibidem, s. 3.

${ }^{36}$ S. Freud, Totem i tabu: Kilka zgodności w życiu psychicznym dzikich i neurotyków, KR, Warszawa 1997; R. Girard, Kozioł ofiarny, Wydawnictwo Łódzkie, Łódź 1987.

37 J. Sieradzan, Nekromania i autorytaryzm polskiej psyche w kontekście Fromma i Adorna, „Albo/albo” 4/2009, ss. 61-66.

${ }^{38}$ E. Fromm, Wojna w człowieku. Psychologiczne studium istoty destrukcyjności, Gdańska Inicjatywa Wydawnicza, Gdańsk 1991, ss. 9-11.

39 Ibidem, s. 9. 
Nekrofil uznaje życie wyłącznie za realizację swoich fantazji na temat przeszłości. Zamiast realizować się w życiu, czyli poszukiwać swojej prawdziwej natury i żyć w zgodzie z nią, wybiera to, co najprostsze, czyli dobrobyt materialny. Za swoją naturę uznaje iluzję odbicia w lustrze. Nie dostrzega, że jest nią samo lustro. Nie jest więc tak, że nekrofilia i sadyzm się wykluczają, jak w wierszu Ryszarda Krynickiego:

Nekrofil przegrał

i sadysta zapanował nad nami ${ }^{40}$.

W omawianym tu kontekście bliższe prawdy okazują się słowa Stanisława Ignacego Witkacego, które (sprafrazowane, bo Witkacy pisał o komunistach i faszystach) brzmią:

Nekrofil czy sadysta

Jam w tym serze jako glista ${ }^{41}$.

\section{7. Żołnierze a mafiosi}

Wykonywanie wyroków śmierci było w AK sformalizowane. Dokonywała je z reguły ustalona grupa likwidacyjna. W kamorze za każdym razem wyrok śmierci mogą wykonać inni ludzie. Preferuje się jednak znajomych, gdyż osłabia to czujność ofiary.

Ani Dąmbski, ani kamoryści i mafiosi nie czują żadnych wyrzutów sumienia z powodu zabijania ludzi. Dąmbski co prawda miał świadomość, że zabicie ważnego urzędnika niemieckiego spowoduje represje i mordy na ludności cywilnej („Niemcy spacyfikują całe Hyżne. Co dziesiąty Polak w tej wiosce zostanie rozstrzelany”), ale nie miało to dla niego żadnego znaczenia ${ }^{42}$.

Mafiosi uważają się za żołnierzy walczących o słuszną sprawę grupy plemiennej z Palermo (nazwa Cosa nostra oznacza „Nasza sprawa”), w związku z czym nie odczuwają wyrzutów sumienia z powodu zabijania:

Morderstwo nie jest dla mafiosa trudnym zadaniem. W każdym razie nie trudniejszym niż dla żołnierza. [...] Tym, czym dla świata jest organizacja przestępcza, tym dla mafiosów jest społeczeństwo, legalne państwo i naród. I dlatego mafioso nie odczuwa wyrzutów sumienia, gdy kogoś zabije. Interesuje go jedynie osąd jego własnego narodu, a nie obcych. Tak samo jak żołnierza, który walczy na wojnie i który też nie ma poczucia winy ${ }^{43}$.

${ }^{40}$ R. Krynicki, Czytajq̨c Fromma, w: idem, Wybrane wiersze i przekłady, Znak, Kraków 1989, s. 91.

${ }^{41}$ S.I. Witkiewicz, Szewcy, w: idem, Dramaty, PIW, Warszawa 1983, s. 431.

42 S. Dąmbski, Egzekutor, s. 21.

${ }^{43}$ P. Reski, Mafia, s. 19. 
Wyrzuty sumienia mają wtedy, gdy zdradzili „swoich”, czyli złamali przysięgę milczenia i przeszli na stronę prawa włoskiego. Podobnie jak wychowanie patriotyczne w przypadku Dąmbskiego, na wyborze drogi życiowej ludzi mafii zaważyło wychowanie w duchu wierności zasadom obowiązującym na Sycylii. Skruszony zabójca Leonardo Messina nie widzi żadnej sprzeczności między religią a zbrodnią:

Wpojono mi, że mafia jest po to, aby wymierzać sprawiedliwość. Zatem sprzeczność nie istnieje. Przeciwnie, to raczej dziś czuję się jak jakiś zdrajca. Kiedyś, gdy byłem mordercą, szedłem odprężony do kościoła. Teraz, gdy jestem odstępcą, nie mogę już się modlić ze spokojnym sumieniem ${ }^{44}$.

W analogiczny sposób, Dąmbski bez emocji opisał przypadkowe zabicie podczas jednej z akcji współpracującego z AK granatowego policjanta ${ }^{45}$.

Sąd AK wydawał wyroki bez udziału sądzonego. Jeśli sprawa dotyczyła kogoś z oddziału, to wyrok wykonywał kolega z oddziału, strzelając w tył głowy ${ }^{46}$. W identyczny sposób, strzałami w tył głowy, oddział Egzekutora zabił kilkudziesięciu pojmanych żołnierzy Wehrmachtu ${ }^{47}$. Po wykonaniu wyroku Egzekutor upijał się („urżnięty jak świnia usnąłem w ubraniu, czekając na lepsze jutro”) ${ }^{48}$.

Skalę demoralizacji Egzekutora pokazuje spotkanie z nagim żołnierzem niemieckim, uprzednio obrabowanym ze wszystkich osobistych rzeczy przez polskich wieśniaków:

A biedny Szkopina siedział przede mną w stroju Adama. Znalazłem się w głupiej sytuacji, bo nie widziałem, co z nim zrobić. Nie mogłem się rozebrać, oddać mu swojego ubrania i wrócić nago na kwaterę. Nie mogłem również pozwolić na jego powrót do Niemiec, gdzie miałby szansę opowiedzieć, jak go ludność w Polsce potraktowała. Opanował mnie ogromny żal, zrobiło mi się po raz pierwszy przykro, że muszę uczestniczyć w wojnie tak bezwzględnej. Bez słowa wyciągnąłem zza pasa parabellum i strzeliłem Niemcowi między oczy ${ }^{49}$.

Innymi słowy, zabił człowieka, bo nie chciał, aby ten opowiedział, jak został potraktowany przez Polaków. Być może chodziło mu o „dobre imię” bądź „honor” Polaków, cokolwiek mogło to znaczyć w tym kontekście. O zamordowaniu śpiącego żołnierza radzieckiego poprzez wbicie mu w głowę gwoździa pisał, że zrobił to: „Bez żadnej emocji, bez skrupułów, wsiadłem na rower i ruszyłem w dalszą drogę" 50 .

\footnotetext{
44 Ibidem, s. 99.

45 S. Dąmbski, Egzekutor, ss. 22-23.

46 Ibidem, s. 37.

47 Ibidem, s. 50.

48 Ibidem, s. 46.

49 Ibidem, s. 51.

50 Ibidem, s. 55.
} 
Podobnie jak Niemców i Rosjan, Egzekutor bez litości i bez skrupułów mordował polskich komunistów. Czynił tak, jak pisze, na polecenie Komendy Głównej $\mathrm{AK}^{51}$.

\section{Szaleństwo patriotyzmu}

Słowo „patriotyzm” nie dla wszystkich ma konotacje pozytywne. Angielski leksykograf Samuel Johnson pisał (w 1775 r.): „Patriotyzm to ostatnie schronienie szubrawców”52. Jedni odróżniają (pozytywny) patriotyzm od (negatywnego) nacjonalizmu, ale inni je z sobą utożsamiają. O ile według Charles’a de Gaulle’a patriotyzm to miłość do własnego narodu, a nacjonalizm to nienawiść do innych narodów ${ }^{53}$, to zdaniem Fromma zarówno patriotyzm, jak i nacjonalizm to formy szaleństwa ${ }^{54}$.

Dąmbski obarcza wychowanie w duchu patriotycznym winą za zabicie w nim ludzkich uczuć i przemianę w bezlitosnego zabójcę. Uważa, że doprowadziło go ono do „zwierzęcego stadium”:

Gdy strzelało się do człowieka, który mówi tym samym, co ja językiem, którego nieraz nawet znało się od lat, trudno jakoś było wytłumaczyć się przed własnym sumieniem. W imię czego i co nas skłaniało do popełniania czynów, które w cywilizowanym świecie równały się prawie morderstwu? Czy robiło się to „w imię Ojczyzny”, czy był to tak zwany zakres działań wojennych?

Naszym obowiązkiem był ślepy posłuch, powiązany z wrodzonym patriotyzmem. Naszym obowiązkiem było pokazać światu, że Polak nigdy się nie podda i że za „waszą i naszą wolność” będzie ginął z uśmiechem na ustach. Ale w rzeczywistości też często, póki żył, mordował wszystkich, którzy nie byli po jego stronie lub też nie zgadzali się $\mathrm{z}$ jego ideami $-\mathrm{z}$ zupełną aprobatą naszego dowództwa. [...]

Przez lata po zakończeniu wojny próbowałem analizować siebie samego i w końcu uznałem, że doszedłem do tego zwierzęcego stadium głównie przez moje wychowanie w młodych latach - w atmosferze do przesady patriotycznej. [...] Gdy się dziecku wmawia od kolebki, jak ważna jest Ojczyzna i że trzeba za nią walczyć z nieprzyjacielem aż do śmierci lub zwycięstwa, to to dziecko, gdy dorośnie, będzie walczyć na rozkaz i strzelać do każdego, kto ma inne poglądy lub jest innej narodowości ${ }^{55}$.

Dla Dąmbskiego, podobnie jak dla innych patriotów, patriotyzm oznacza tkwienie w błędnym kole zbrodni. Jest to nabyta przez wychowanie umiejętność zabijania obywateli innych krajów, zapewne również wychowanych w duchu patriotycznym, czyli z wpojoną umiejętnością zabijania obywateli innych krajów.

51 Ibidem, s. 58.

52 Patriotism is the last refuge of a scoundrel, http://www.samueljohnson.com/refuge.html [24.08.2017].

53 Nacjonalizm, https://pl.wikiquote.org/wiki/Nacjonalizm [29.04.2017].

54 E. Fromm, Zdrowe społeczeństwo, PIW, Warszawa 1996, s. 69.

55 S. Dąmbski, Egzekutor, ss. 114-115. 


\section{9. Święci zabójcy: religia a zbrodnia}

„Byłem zawsze bardzo wierzący, w dzieciństwie służyłem jako ministrant u salezjanów [...] Zanim byłem zmuszony kogoś zabić, zawsze robiłem znak krzyża. Mówiłem: »Drogi Boże, dopomóż mi! Spraw, żeby nic się nie stało! « Nie tylko ja jeden żegnałem się i modliłem do Boga. Wszyscy to robiliśmy”56.

mafioso Marcello Fava

Zarówno Dąmbski, jak również mafiosi i kamoryści to katolicy. Opowieści o zabijaniu Egzekutor przeplata ze wspomnieniami o swoim katolickim wychowaniu. W jego umyśle katolicyzm i zbrodnia przeplatają się i uzupełniają:

Byłem od dziecka wychowany w bardzo religijnej atmosferze, jako młody chłopak udzielałem się wiele, chodziłem co tydzień do spowiedzi, w każdy pierwszy piątek miesiąca przyjmowałem komunię świętą i często służyłem do mszy - w wielu wypadkach właśnie księdzu Ostrowskiemu [...] Idąc nieraz na roboty [wykonywanie wyroków J.S.], robiłem po cichu układy z Panem Bogiem, że jeśli mi się poszczęści i danego skurczybyka odpowiednio naszpikuję ołowiem, to przez następny tydzień będę dobry i czysty w umyśle, mowie i uczynku ${ }^{57}$.

Ów ksiądz Ostrowski odegrał pewną rolę w życiu Dąmbskiego, ponieważ nakłonił go do zamordowania w grudniu 1944 r. pewnego AK-owca, który rozpoczął współpracę z organami władzy komunistycznej. W wyniku podjętej akcji oddział Dąmbskiego zabił wszystkich polskich milicjantów z posterunku. Ten dokonany z zimną krwią mord dał mu do myślenia: „Pierwszy raz zacząłem sobie uświadamiać, że może ta partyzantka to przegrana sprawa, że te poświęcenia i tragedie nie mają wiele sensu"58.

Skazanej na śmierć za zdradę młodej i atrakcyjnej kobiecie, po odczytaniu wyroku Dąmbski daje „dziesięć minut na modlitwę i pożegnanie się z rodziną”59. Po jej zabiciu Dąmbski odczuwa coś w rodzaju wyrzutów sumienia: „dlaczego? Było to pytanie, które dręczyło mnie tygodniami”60.

Katolicki zakonnik Nino Fasullo powiedział: „Nie ma ani jednego mafiosa, który nie byłby religijny”61. We Włoszech kler katolicki ściśle współpracuje z kamorrą, nigdy nie krytykuje jej poczynań ani nie odmawia udzielania sakramentów, choć wie, że w ten sposób uświęca zbrodnię. „Rodziny mafijne, a zwłaszcza bossowie

56 P. Reski, Mafia, ss. 27, 10.

57 S. Dąmbski, Egzekutor, s. 66.

58 Ibidem, s. 85.

59 Ibidem, s. 33.

60 Ibidem, s. 34.

61 Cyt. za: P. Reski, Mafia, s. 106. 
o szczególnej charyzmie, często myślą o swoim działaniu jak o ciężkim krzyżu niesionym dla dobra innych" ${ }^{2}$. Jeden z klanów kamorry sfinansował odnowienie fresku Madonny Kamorry, przed którym modlili się wszyscy lokalni bossowie ${ }^{63}$.

Kamoryści wierzą w magię liczby 33, nawiązującej do domniemanej długości życia Jezusa: tną haszysz seriami po 33, przerywają pracę na 33 minuty, robią znak krzyża i kontynuują swoją pracę. Torebki z kokainą przed sprzedażą dilerzy skrapiają wodą z Lourdes „,w nadziei, że dzięki temu nikogo nie zabiją”64. W kryjówce, w której boss mafii Bernardo Provenzano ukrywał się przez wiele lat, znaleziono 91 figur Jezusa, Maryi i świętych oraz pięć egzemplarzy Biblii z zakładkami i podkreślonymi fragmentami, świadczącymi o uważnej lekturze ${ }^{65}$.

Kilku kamorystów nie chciało wykonać wyroku wydanego na (jedynym, co podkreśla Saviano) księdzu katolickim, który publicznie krytykował działalność kamorry; znaleźli się jednak tacy, którzy nie mieli żadnych skrupułów i wykonali to zlecenie ${ }^{66}$.

Najpopularniejszy włoski święty katolicki XX wieku Pio Forgione (zwany Ojcem Pio) cieszy się w kręgu przestępców równie wielkim kultem jak Jezus czy Maria $^{67}$. Dla sycylijskich mafiosów jego posąg służył jako miejsce ukrycia narkotyków ${ }^{68}$. Saviano opisał, jak po dokonaniu morderstwa kamoryści odpoczywają pod jego posągiem:

Zastrzelili kobietę z odkrytymi twarzami, potem usiedli niedaleko na ławce, pod posągiem Ojca Pio. [...] W chwili aresztowania jeden z nich, widząc kamery telewizyjne i flesze aparatów fotograficznych, uśmiechnął się i mrugnął do dziennikarzy. [...] Śledztwo potwierdziło, że mordercy wrócili na miejsce zabójstwa. [...] Jakby patrzyli na film, w którym najpierw grali główne role, a potem z drugiego planu śledzili rozwój wypadków ${ }^{69}$.

Hannah Arendt zauważyła, że naziści sądzeni przed sądem za zbrodnie popełnione w obozie w Oświęcimiu, uśmiechali się podczas odczytywania listy ich czynów i skłaniali się w kierunku swoich dawnych ofiar ${ }^{70}$. Jedna z niedoszłych ofiar Aniołów Śmierci, zwanych też Zabójcami Zebry, seryjnych zabójców działających w Kalifornii w pierwszej połowie lat 70. XX wieku, powiedziała policji, że zanim zaczęli do niej strzelać, uśmiechnęli się i powiedzieli „cześć!”71.

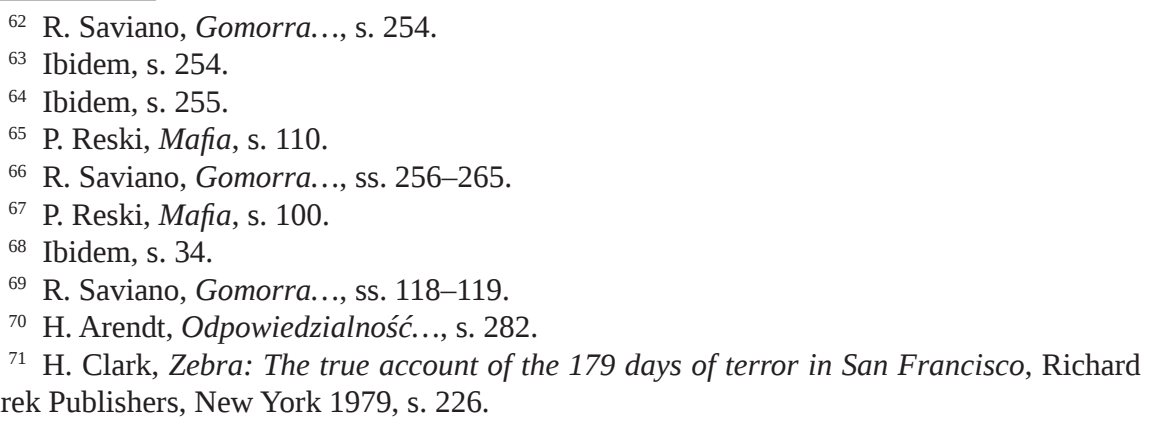




\section{Popkulturowi gangsterzy}

„Jestem mafiosem i jestem z tego dumny”72.

Vittorio Emanuele Orlando (1919)

Mimo wychowania, motywacja Dąmbskiego nie była patriotyczna. Wstępując do AK, marzył o życiu pełnym emocji, które przyniesie mu sławę. Niezadowolony z życia prostego żołnierza, zgłosił się do dywersji ${ }^{73}$. Zdaniem Dariusza Stoli Dąmbski „dziś by się nadawał na bohatera kina akcji”74.

Wzorami dla kamorystów są znane postacie popkultury. Opisanym przez Saviano kamorystom imponowało wczuwanie się w ulubione postaci filmowe. Ich ideałem nie jest Al Capone, wzór dla gangsterów rosyjskich lat 80. i 90. XX wieku. O ile starsi kamoryści wzorowali się na Alu Pacino z „Człowieka z blizną”, to ci z początku XXI wieku zachowują się jak zabójcy z filmu „Pulp Fiction”, a kobiety jak Uma Thurman z filmu „Kill Bill”. Najbardziej popularny w środowisku kamorry jest film „Kamorysta” Giuseppe Tornatore ${ }^{75}$. Także pseudonimy kamorystów nawiązują do postaci popkultury. Wśród ich bohaterów są Zorro, Kojak, Rambo, Kit Kat i Pikachu (postać z japońskiej kreskówki) ${ }^{76}$. Ich ideałem jest „człowiek interesu otoczony pięknymi modelkami”77.

W zmedializowanym świecie przestępcy nie tylko nie ukrywają swoich zbrodni, ale nawet się nimi chełpią. W filmie „15 minut” jeden z dwóch przestępców z Europy Wschodniej działających w Nowym Jorku filmuje zbrodnie swojego kolegi, chcąc je utrwalić dla potomności. Mafiosi z Palermo jako jedni z pierwszych kupują książki o mafii i szukają w nich informacji o sobie: „»Jest w tej książce coś o panu? « - zapytałam. I Fava odparł: »Tak, na stronie pięćset sześćdziesiątej ósmej«. Powiedział to z dumą. Zupełnie jak ktoś, kto ma swoje hasło w Encyklopedii Britannica"78. Znany jest też przypadek mafiosa, który w powieści Ojciec chrzestny Mario Puzo znalazł i wykorzystał w praktyce metodę pozbycia się skazanego przez organizację człowieka ${ }^{79}$.

${ }^{72}$ Cyt. w: J. de Saint Victor, Niewidoczna siła..., s. 109.

73 S. Dąmbski, Egzekutor, s. 15.

74 Przemoc chwalebna..., s. 14.

${ }^{75}$ R. Saviano, Gomorra..., ss. 128-129, 278-287. Jacques de Saint Victor nazwał film Briana de Palmy „biblią młodzieży z przedmieść”. Zob. Niewidoczna siła, s. 298.

${ }^{76}$ R. Saviano, Gomorra..., ss. 67, 118-121, 312,

77 Ibidem, s. 127. Jeden z kamorystów powiedział, że ożeni się z czarną modelką albo Niemką. Ibidem, s. 126.

${ }^{78}$ P. Reski, Mafia, s. 27.

${ }^{79}$ M.-A. Matard-Bonucci, Historia mafii, ss. 187-188. 


\title{
11. Biznes, kamorra, wojna
}

\author{
„Biznes to wojna”80. \\ Mark McNeilly
}

Między wojną a biznesem nie ma żadnej różnicy, a w odniesieniu sukcesu ekonomicznego pomogło Japończykom zastosowanie do biznesu zasad Sztuki wojny Sun Zi (około V wieku p.n.e.) ${ }^{81}$. Dąmbski był produktem wojny, kamoryści są produktami równie bezlitosnego neoliberalizmu. Interesy kamorry to kapitalizm w najczystszym wydaniu. Wszystko jest w nim podporządkowane zyskowi ${ }^{82}$. Jak zauważył Saviano: „Zagrożenie dla biznesu jest równoznaczne z zagrożeniem dla życia"83. Ale sycylijscy mafiosi są chyba jeszcze zakorzenieni w feudalizmie. Może o tym świadczyć to, że - jak średniowieczni feudałowie - kojarzą małżeństwa swoich dzieci z osobami z innych krajów, aby uniknąć wojen o stery wpływów ${ }^{84}$.

Francuski historyk i prawnik Jacques de Saint Victor - powołując się na dzieła socjologów Thorsteina Veblena, Raymonda Arona i Pino Arlacchiego oraz ekonomisty Josepha Schumpetera - pisał „o pokrewieństwie porządku kapitalistycznego

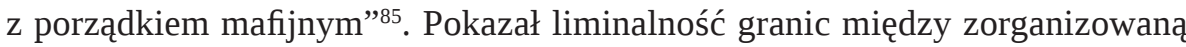
przestępczością a systemem finansowym:

Kapitalizm finansowy spłodził finansowych superdrapieżników, których działania przypominają przestępczość bandytów w białych kołnierzykach i przestępczość korporacyjną, a ich przewrotne metody godne są metod zorganizowanych band: są to zwykli rabusie, którzy nie wahali się złupić swoich własnych klientów, spekulować ze szkodą dla państwa, któremu doradzają, i oszukiwać przedstawicieli narodu, dziwiąc się, że ci ośmielają się domagać odpowiedzialności za czyny, które milionom rodzin odebrały środki do życia ${ }^{86}$.

Ofiarami wojny i gry biznesowej padają często niewinni ludzie. Podczas jednej z akcji opisanych przez Dąmbskiego zginęło kilka przypadkowych osób, w tym 10-letnia dziewczynka, a jeden z kolegów Dąmbskiego przypadkowo zabił innego egzekutora ${ }^{87}$. Według Saviano interesy kamorry to wojna, która za-

${ }^{80}$ M. McNeilly, Sun Tzu and the Art of Business: Six Strategic Principles for Managers, Oxford University Press, New York 1996, s. 12.

${ }^{81}$ Ibidem, ss. 11-12.

${ }^{82}$ R. Saviano, Gomorra..., ss. 130-132.

83 Ibidem, s. 94.

${ }^{84}$ Jeden z mafiosów ożenił się z córką narkotykowego barona z Kolumbii. Zob. P. Reski, Mafia, s. 51.

85 J. de Saint Victor, Niewidoczna siła..., s. 310.

${ }^{86}$ Ibidem, ss. 318-319.

87 S. Dąmbski, Egzekutor, ss. 102-107. 
raża wszystkich znajdujących się na jej terytorium: „Machina kamorry miażdży ludzi bez winy" ${ }^{88}$. W wendettach kamorry, podobnie jak podczas wojny, padają przypadkowe ofiary. Jedną z nich była 14-latka ${ }^{89}$. Mafie prowadzą wojnę totalną przeciwko ludziom skazanym przez nie na śmierć. Gdy egzekutorzy mafii bądź kamorry nie są w stanie zabić innego mafiosa, zabijają tylu członków jego rodziny, ilu są w stanie znaleźćco

\section{Homo homini lupus est}

W świecie zwalczających się plemion zawiera się doraźne sojusze mające na celu pozbycie się wrogów. Choć w czasie wojny Dąmbski zabijał głównie Niemców i polskich kolaborantów, to po wycofaniu się Niemców z Polski zabijał wszystkich, bez względu na przynależność narodową. Z jego wspomnień wynika, że Ukraińców nienawidził bardziej od Niemców, Rosjan i polskich komunistów. We współpracy z komunistycznymi milicjantami zabijał Ukraińców podejrzewanych o dokonywanie czystek etnicznych na Polakach:

W likwidacjach Ukraińców pomagała nam też miejscowa Milicja Obywatelska. Mieliśmy jeden „swój” posterunek [...] który pomagał nam w ten sposób, że po aresztowaniu Ukraińców podejrzanych o palenie polskich wiosek, po prostu oddawał nam ich na odstrzał. Zamiast odwozić do komendy głównej lub do sądów, dawali nam znać przez łącznika, że taki a taki Ukrainiec czeka na nas na posterunku i jest do odebrania. Wtedy była robota tylko dla mnie i „Twardego”91.

Potem, wraz z kapralem „Twardym”, zabijali go.

We współpracy z komunistyczną milicją Dąmbski dokonał też mordu na grupie przestępczej Fiołków, utrzymującej się z kradzieży: „miejscowa milicja z Wesołej porozumiała się z dowództwem naszej Czternastki co do ich likwidacji. »Draża« [dowódca Dąmbskiego - J.S.] zgodził się łatwo, bo miał zawsze na względzie nasze dobre imię (sic!)”92. Wspominając to zdarzenie, Dąmbski pisał: „Przeprowadziliśmy tę likwidację w imię Ojczyzny..."93

Ten sam brak litości w stosunku do wrogów zauważył Saviano w kamorze:

Zabić wszystkich. Wszystkich. Nawet jeśli masz wątpliwości. Nawet jeżeli nie jesteś pewny, po której stronie stoją twoje ofiary, nawet jeżeli nie wiesz, czy w ogóle stoją po którejś stronie. Wystrzelać! To szlam. Tylko szlam. Gdy toczy się wojna, wobec niebezpieczeństwa przegranej, pozycje sojuszników i przeciwników są wymienne. Nie masz do

88 R. Saviano, Gomorra..., s. 137. Por. ibidem, s. 108.

89 Ibidem, ss. 173-176. Por. ibidem, ss. 59, 109, 112, 230.

90 M.-A. Matard-Bonucci, Historia mafii, ss. 195-196; R. Saviano, Gomorra, ss. 194-195.

91 S. Dąmbski, Egzekutor, s. 90.

92 Ibidem, s. 98.

93 Ibidem, s. 107. 
czynienia z realnymi ludźmi, tylko obiektami, na których wypróbowujesz własną siłę. Dopiero później, kiedy sytuacja trochę się uspokoi, będzie można rozgraniczyć przeciwne strony, rozróżnić sprzymierzeńców i wrogów. Ale na razie trzeba tylko strzelać ${ }^{94}$.

Uderza infrahumanizacja (dehumanizacja) ofiar dokonana przez młodocianych morderców. Kamoryści nazywają zabitych przez siebie ludzi sztukami, tak jakby mówili o bydle ${ }^{95}$. Uprzednio naziści porównywali Żydów i Romów do szczurów, bakterii, robactwa i zarazków ${ }^{96}$.

\section{Kapitalistyczna kryminalizacja uczciwości}

W obecnych czasach zamazanych granic między uczciwością i nieuczciwością można zauważyć, że państwa przegrywają w starciu z ponadpaństwowymi korporacjami, a nawet ze zorganizowaną przestępczością. Były prezes włoskiego związku pracodawców Luca Cordero di Montezemolo nazwał w 2007 r. uczciwą działalność handlową „heroizmem”97.

Jeśli chodzi o płacenie podatków, to w wielu wypadkach granica między korporacjami a organizacjami przestępczymi zupełnie zanikła. Chodzi tutaj o stosowanie optymalizacji podatkowej przez wielkie korporacje. Istnieje aż 600 instrumentów optymalizacji podatkowej. Polega ona na budowaniu fikcyjnej sieci spółek-córek i ruchach pieniędzy między nimi. Sposób, w jaki to się odbywa, opisał Dominik Gajewski: „Zwykle chodzi o zejście na 3\%. Jest mniej więcej tak: robi pan trzy ruchy między spółkami i wtedy, zamiast płacić 19\% podatku, płaci jakieś 6-7\%. Sześć ruchów - można zejść na 3\%. A może pan zrobić osiemnaście ruchów i wtedy będzie zero"98. Albo 0,005\% (stawka, którą władze Irlandii pozwoliły opodatkować firmie Apple zyski z całej Europy) ${ }^{99}$. Wskutek tego w 2016 r. firma Apple nie zapłaciła 13 mld zaległych podatków w samej tylko Irlandii, a Facebook, który także obraca miliardami, w 2014 r. zapłacił zaledwie 4327 funtów podatku w Wielkiej Brytanii ${ }^{100}$. Paradoks polega na tym, że gdy Unia Europejska nakazała firmie Apple zapłacenie zaległych podatków, „rząd irlandzki odmówił ich przyjęcia”101 w obawie przed tym, że Apple opuści Irlandię.

${ }^{94}$ R. Saviano, Gomorra..., s. 96.

95 „Wyrażenie »załatwić jedną sztukę« zostało zapożyczone z żargonu pracujących na akord; o śmierci człowieka mówi się tak samo jak o wyprodukowaniu jakiegoś przedmiotu”. Ibidem, s. 121.

${ }^{96}$ F. de Fontette, Historia antysemityzmu, Siedmioróg, Wrocław 1992, s. 94.

${ }^{97}$ Cyt. za: J. de Saint Victor, Niewidoczna siła..., s. 284.

${ }^{98}$ Polska to głupi raj podatkowy. Z prof. Dominikiem Sroczyńskim rozmawia Grzegorz Sroczyński, „Duży Format”, dodatek do „Gazety Wyborczej” nr 16 z 2017 r., s. 3.

${ }^{99}$ Ibidem.

100 Ibidem.

101 A. Grzeszak, Czterej jeźdźcy @pokalipsy, „Polityka” nr 16 z 2018 r., s. 15. 
W niektórych młodych demokracjach Europy Wschodniej rządy nazywające się demokratycznymi sprawuje w istocie jedna osoba. Niektórzy mieszkańcy Zachodu uznają za zrozumiałe, że zanim ludzie docenią wartość rządów prawa, muszą przejść przez okres dyktatury. Jednak również stare, mieszczańskie demokracje zachodnie dostosowują prawo do własnych bieżących potrzeb. Weźmy jako przykład Austrię, która po kryzysie w 2008 r. w obliczu spadku eksportu o $2 \underline{0}$ p.p. zaprosiła wielkie korporacje, oferując im 6-procentową stawkę podatkową przy znacznie wyższej obowiązującej w innych krajach. Gdy poszkodowani tym działaniem Czesi odwołali się do Unii Europejskiej, ta po kilkunastu miesiącach procedury sprawdzającej nakazała Austrii zmianę prawa. Austriacy uczynili to 31 grudnia, a 1 stycznia następnego roku wprowadzili nowe, niewiele różniące się od poprzedniego. Widząc reakcję Austriaków, Czesi i Słowacy zaczęli swoją grę, tym razem kosztem Polski. Wskutek tego polscy przedsiębiorcy zaczęli rejestrować firmy i rozliczać się w Czechach i Słowacji. Chociaż stawki podatkowe są tam takie same jak w Polsce, to jednak rozmaite ulgi powodują obniżenie podatku z 19 do około 2\%. Przy zerowych kosztach do czeskiego i słowackiego budżetu wpływają setki milionów euro. Koszty (remonty dróg, obsługa prawna i medyczna, emerytury itp.) ponosi państwo, w którym dana firma faktycznie działa, a nie to, w którym firma płaci podatki. Większość największych korporacji jest zarejestrowana w Luksemburgu, gdzie płaci 1\% podatku CIT, dzięki ulgom wprowadzonym jeszcze w latach 50 . XX wieku, choć jego normalna stawka wynosi obecnie $29 \%{ }^{102}$.

To zmusza do nieuczciwego działania uczciwych uczestników gry rynkowej. Bezwzględna logika kapitalizmu polega na kryminalizacji uczciwych przedsiębiorców. Nie chcąc wypaść z gry, przechodzą na ciemną stronę mocy i zaczynają stosować optymalizację podatkową, płacąc minimalne podatki. Na tym procederze Europa traci rocznie 300 mld euro, a Polska 46 mld euro ${ }^{103}$. Pozbywanie się ludzi o czystych rękach jest, jak się wydaje, jedną z cech kapitalizmu, w którym niejasne powiązania między grupami interesów zastępują uczciwą grę rynkową ${ }^{104}$.

W tym miejscu trzeba też postawić pytanie o różnicę między kryminalnym postępowaniem rządu mającego mandat wyborczy czy legalnie działającymi korporacjami a grupami przestępczymi produkującymi tzw. dopalacze. Ci ostatni stosują prostą metodę przypominającą tę, które stosowała Austria, dopasowując swoje prawo do żądań Unii Europejskiej:

102 Polska to głupi raj podatkowy..., s. 2.

103 Ibidem, s. 3.

104 Zjawisko to jest znane także w krajach azjatyckich. W Chinach: „Jeśli jakiś urzędnik próbuje zachować czyste ręce, inni uznają, że łamie zasady, i szybko się go pozbędą”. Pin Ho, Wenguang Huang, Uderzenie w czerń. Morderstwo, pieniq̨dze i walka o władzę w Chinach, Czarne, Wołowiec 2015, s. 296. W innym miejscu tej książki czytamy, że „podziały między frakcjami nie są przeszkodą dla korupcji, którą skażeni są właściwie wszyscy urzędnicy”. Ibidem, s. 324. W Indii: „Jeśli ktoś zajmuje wysokie stanowisko, którego nie wykorzystuje, jeśli nie daje zarobić wszystkim wokół, to jest poważnie zagrożony”. Zob. R. Dasgupta, Delhi: Stolica ze złota i snu, Czarne, Wołowiec 2016, ss. 336-337. 
Producenci środków psychoaktywnych są bowiem w stanie szybko zmodyfikować ich skład, tak aby substancje zawarte w dopalaczu nie znajdowały się na liście substancji zabronionych i „wymknęły się” spod zakazu sprzedaży. W ten sposób organy państwa pozostają nieustannie o krok za podmiotami wytwarzającymi i wprowadzającymi dopalacze do obrotu ${ }^{105}$.

Prezydent Rosji Władimir Putin mówi o władzach Zachodu „nasi partnerzy”106. Tego samego sformułowania wobec policji używa lider grupy przestępczej w filmie „Zakładnicy z metra”107. I Putin, i filmowi porywacze wciągają siły stojące na straży prawa do własnej gry. Putin czyni to, oprowadzając reżysera Olivera Stone’a po Kremlu. Pokazał mu, na przykład, pokój, w którym decyduje o życiu i śmierci obywateli Rosji i krajów z nią sąsiadujących. Lider porywaczy czyni to, wciągając do gry pracowników telewizji i żądając, aby emitując nagrane z nim wywiady, zapewnili mu żądany okup. Obaj domagają się od swoich „partnerów” odegrania roli, jaką dla nich napisali w swoich scenariuszach.

Saviano pokazał, że szerokie poparcie, jakim cieszy się kamorra w społeczeństwie, nie wynika ze strachu, ale z tego, że organizacja ta daje ludziom pewność zatrudnienia, możliwość szybkiego awansu nawet bardzo młodym ludziom, aresztowanym udziela wsparcia prawnego, a ich rodzinom finansowego. Płatnym zabójcom poszukiwanym przez policję umożliwia ucieczkę za granicę i finansuje jego koszty ${ }^{108}$.

Członkowie klanu mają zagwarantowaną ochronę fizyczną, wynagrodzenie oraz, w razie potrzeby, opiekę prawną opłacaną przez klan ${ }^{109}$.

[Kasjerzy klanu d]zwonią do drzwi 28 każdego miesiąca, kładą na stole plastykową siatkę, a z wypchanej kieszeni marynarki wyciągają plastykową kopertę podpisaną nazwiskiem zmarłego lub uwięzionego kamorysty i dają ją żonie lub, w razie jej nieobecności, najstarszemu synowi. Prawie zawsze razem z wypłatą przynoszą zakupy ${ }^{110}$.

Kamorra działa jak sprawne przedsiębiorstwo w regionie o ogromnym bezrobociu. W razie bankructwa współpracownika, nie wyrzuca go na bruk po zabraniu mu sklepu (jak uczyniłby działający legalnie bank), ale przejmuje jego sklep na własność. Dawny właściciel nadal pozostaje pracownikiem kamorry, a ta wypłaca mu miesięczną pensję. W ten sposób kamorra przejęła na własność połowę sklepów w Neapolu ${ }^{111}$.

105 D. Gajos-Kaniewska, NIK. Polska przegrywa walkę z dopalaczami, „Rzeczpospolita” z 3.06.2017 r., http://www.rp.pl/Zdrowie/306039953-NIK-Polska-przegrywa-walke-zdopalaczami.html\#ap-1 [12.08.2017].

106 Oliver Stone vs Władimir Putin, reżyseria Oliver Stone, USA, 2017.

107 Zakładnicy z metra, reżyseria Kasper Barfoed, Dania, 2017.

108 R. Saviano, Gomorra..., s. 100.

109 Ibidem, s. 299.

${ }^{110}$ Ibidem, s. 159. Uzupełnienia w nawiasie pochodzą od autora

${ }^{111}$ Ibidem, s. 61. 


\section{Końcowe refleksje: zamazana granica między mafią i antymafią}

Granica między państwem a organizacją przestępczą może stać się płynna. Niejasne albo nieaktualne regulacje prawne oraz spryt inwestorów powodują, że państwa przegrywają w starciu z ponadpaństwowymi korporacjami, a nawet ze zorganizowaną przestępczością.

Liminalność granicy między dobrem a złem nie oznacza tylko, że te same osoby, które w czasie pokoju potępiają zło, podczas wojny chwalą zabijanie. Oznacza także zamianę hierarchii wartości w czasie pokoju. Za przynoszące korzyści, a więc dobre, uznaje się to, co służy mniejszej grupie społecznej istniejącej w ramach większej grupy, np. organizacji przestępczej w państwie, jednemu państwu w ramach wspólnoty państw czy ponadnarodowej korporacji w świecie.

Chociaż zarówno mafia, jak i AK powstały jako samoobrona przeciwko okupantom, odpowiednio Sycylii i Polski, nie należy stawiać znaku równości między państwem a organizacją przestępczą ani patriotyzmem i zabijaniem. Ten artykuł wskazuje tylko na to, o czym piszę od dawna, czyli na liminalność, a więc płynność granic między zjawiskami. Nie każdy patriota stanie się mordercą i tylko niewiele państw można nazwać organizacjami przestępczymi. Istotne jest natomiast to, że pewne decyzje rządów bądź ich brak ułatwiają działanie przestępcom.

W czasie wojny ludzie przyzwyczajają się do zabijania, traktują je jak coś normalnego i naturalnego. Granica między dobrem a złem staje się liminalna. Kler, który podczas pokoju najczęściej potępia zło (choć nie w środowiskach opanowanych przez mafie), w czasie wojny błogosławi żołnierzy idących zabijać.

Na terenie działania kamorry, czyli w Neapolu i okolicach, zbrodnia jest normalnością, a normalność jest traktowana jako coś osobliwego i niezrozumiałego. Kobieta, która była świadkiem morderstwa dokonanego przez kamorystę i złożyła obciążające go zeznanie, straciła wszystko: rodzinę, narzeczonego i perspektywy normalnego życia. Została sama ${ }^{112}$. To samo stało się z Roberto Saviano, który w obawie przez zemstą kamorystów musi się ukrywać. Zrównało to status członków kamorry i ludzi, którzy z nią walczą - wszyscy muszą się ukrywać: pierwsi przed policją, drudzy przez kamorrą. W ten sposób zamazuje się różnica między mafią i antymafią.

Chęć poprawy swojego statusu prowadzi do kryminalizacji życia (Dąmbski, kamoryści) i życia w ciągłym strachu ${ }^{113}$. Zarówno żołnierze podziemia, jak i kamoryści, aby przeżyć, muszą zabijać. Nawet zostanie szefem nie daje gwarancji

112 R. Saviano, Gomorra..., ss. 312-314.

113 Ten sam los stał się udziałem tych, którzy zbuntowali się przeciw dyktatorskim rządom w kilku krajach islamskich w 2011 r. Zamiast poprawy swojej egzystencji, doczekali się rozpadu państw i wojen domowych. 
nietykalności, bo można zostać zdradzonym i zabitym. Bezpieczeństwa i spokoju ani żołnierze, ani kamoryści, ani Saviano (od lat pozostający pod ochroną policji) nie kupią za żadną cenę. Szaleństwo staje się nową normą. Chcąc przeżyć, trzeba się do nowej sytuacji przystosować. W takim świecie dobro i zło stają się słowami bez znaczenia.

\section{Literatura cytowana}

Arendt H., Odpowiedzialność i władza sq̨dzenia, Prószyński i S-ka, Warszawa 2006.

Bouček J., Ośmiornica. Historia sycylijskiej mafii, Marpress, Gdańsk 1992.

Brydone P., A Tour Through Sicily and Malta, vol. 1, W. Strahan and T. Cadell, London 1773.

Burkert W., Home Necans: The Anthropology of Ancient Greek Sacrificial Ritual and Myth, University of California Press, Berkeley 1983.

Clark H., Zebra: The true account of the 179 days of terror in San Francisco, Richard Marek Publishers, New York 1979.

Dasgupta R., Delhi. Stolica ze złota i snu, Czarne, Wołowiec 2016.

Dąmbski S., Egzekutor, Wydawnictwo Naukowe PWN, Warszawa 2013 (seria: Literatura Faktu PWN).

Debord G., Rozważania o społeczeństwie spektaklu, w: idem, Społeczeństwo spektaklu. Rozważania o społeczeństwie spektaklu, PIW, Warszawa 2006.

Fontette F. de, Historia antysemityzmu, Siedmioróg, Wrocław 1992.

Freud S., Totem i tabu. Kilka zgodności w życiu psychicznym dzikich i neurotyków, KR, Warszawa $1997\left(1913^{1}\right)$.

Fromm E., Wojna w człowieku. Psychologiczne studium istoty destrukcyjności, Gdańska Inicjatywa Wydawnicza, Gdańsk 1991.

Fromm E., Zdrowe społeczeństwo, PIW, Warszawa 1996.

Gajos-Kaniewska D., NIK: Polska przegrywa walkę z dopalaczami, „Rzeczpospolita” z 3.06.2017 r., http://www.rp.pl/Zdrowie/306039953-NIK-Polska-przegrywa-walkez-dopalaczami.html\#ap-1 [12.08.2017].

Girard R., Kozioł ofiarny, Wydawnictwo Łódzkie, Łódź 1987 (1982¹).

Goldhagen D.J., Gorliwi kaci Hitlera: Zwyczajni Niemcy i faszyzm, Prószyński i S-ka, Warszawa 1999.

Grzeszak A., Czterej jeźdźcy @pokalipsy, „Polityka” nr 16 z 2018 r.

Jabłońska U., Ksiqż̇ka śmierci, „Duży Format”, dodatek do „Gazety Wyborczej” nr 29 z $2017 \mathrm{r}$.

Kowalski W., Egzekutor, https://dzieje.pl/ksiazka/egzekutor [26.10.2019].

Krynicki R., Czytajq̨c Fromma, w: idem, Wybrane wiersze i przekłady, Znak, Kraków 1989, 91.

Leder A., Prześniona rewolucja. Ćwiczenie z logiki historycznej, Wydawnictwo Krytyki Politycznej, Warszawa 2014.

Marks K., Rękopisy ekonomiczno-filozoficzne z 1844 r. (Fragmenty), w: idem, Pisma wybrane. Człowiek i socjalizm, PWN, Warszawa 1979.

Matard-Bonucci M.-A., Historia mafii, Grupa Wydawnicza Bertelsmann, Warszawa 2001.

McNeilly M., Sun Tzu and the Art of Business: Six Strategic Principles for Managers, Oxford University Press, New York 1996. 
Mirowski M., Wiesław nieoczywisty, „Polityka” nr 36 z 2017 r.

Nacjonalizm, https://pl.wikiquote.org/wiki/Nacjonalizm [29.04.2017].

Patriotism is the last refuge of a scoundrel, http://www.samueljohnson.com/refuge.html [24.08.2017].

Pin Ho, Wenguang Huang, Uderzenie w czerń: Morderstwo, pieniq̨dze i walka o władzę w Chinach, Czarne, Wołowiec 2015.

Polska to głupi raj podatkowy. Z prof. Dominikiem Sroczyńskim rozmawia Grzegorz Sroczyński, „Duży Format”, dodatek do „Gazety Wyborczej” nr 16 z 2017 r.

Przemoc chwalebna. Z prof. Dariuszem Stolq o ksiqżce Stefana Dq̨mbskiego „Egzekutor” rozmawia Piotr Lipiński, „Duży Format”, dodatek do „Gazety Wyborczej” nr 42 z 2010 r.

Reski P., Mafia, Bellona, Warszawa 2017.

Roberto Saviano: męczennik za prawdę czy zwykły oszust?, Onet, 5.11.2015, http:// ksiazki.onet.pl/roberto-saviano-meczennik-za-prawde-czy-zwykly-oszust/w8npq6 [17.08.2017].

Saint Victor J. de, Niewidoczna siła. Mafia w społeczeństwach demokratycznych, Czarne, Wołowiec 2015.

Saviano R., Gomorra: Podróż po imperium kamorry, Czytelnik, Warszawa 2008 (2006ㄹ).

Sieradzan J., Nekromania i autorytaryzm polskiej psyche w kontekście Fromma i Adorna, „Albo/albo” 4/2009.

Tomański R., Tatami kontra krzesła: O Japończykach i Japonii, Warszawskie Wydawnictwo Literackie Muza, Warszawa 2011.

Turner V., Proces rytualny: Struktura i antystruktura, PIW, Warszawa 2010 (1969¹).

Witkiewicz S.I., Szewcy [w:] tenże, Dramaty, PIW, Warszawa 1983.

Wójcik Ł., Bank populizmu, „Polityka” nr 38 z 2017 r.

Žižek S., Przekleństwo fantazji, Wydawnictwo Uniwersytetu Wrocławskiego, Wrocław 2001.

\section{Filmografia cytowana}

15 minut, reżyseria John Herzfeld, Niemcy/USA, 2001.

Akcja pod Arsenałem, reżyseria Jan Batory, Polska, 1978.

Człowiek z bliznq, reżyseria Brian de Palma, USA, 1983.

Gomorra, reżyseria Matteo Garrone, Włochy, 2008.

Kamorysta, reżyseria Giuseppe Tornatore, Włochy, 1986.

Kill Bill, reżyseria Quentin Tarantino, USA, 2003.

Oliver Stone vs Władimir Putin, reżyseria Oliver Stone, USA, 2017.

Pulp Fiction, reżyseria Quentin Tarantino, USA, 1994.

Zakładnicy z metra, reżyseria Christian E. Christiansen, Dania, 2017. 
